\title{
A BUSCA PELA SATISFAÇÃO DO CRÉDITO TRIBUTÁRIO: protesto de CDA e os impactos no setor privado
}

\author{
Bruno Bastos de Oliveira ${ }^{1}$ \\ Maria das Graças Macena Dias de Oliveira ${ }^{2}$
}

Resumo. A busca pela satisfação do crédito tributário é grande desafio da administração pública. A análise dos aspectos relevantes sobre a possibilidade do protesto da Certidão de Dívida Ativa (CDA) de natureza fiscal, a partir da correta interpretação do texto constitucionais se faz necessária num contexto de crise política e econômica. A confirmação da constitucionalidade do protesto pelo Supremo Tribunal Federal revela vários aspectos, tal como a possível caracterização de sanção política que impacta a atividade empresarial. Nesse ambiente de desestímulo da atividade econômica privada, o protesto de CDA de natureza fiscal se mostra como mais um ingrediente.

Palavras-chave: Protesto; Certidão de Dívida Ativa; Tributário; Atividade empresarial; Desenvolvimento.

\section{THE SEARCH FOR THE SATISFACTION OF TAX CREDIT: CDA protest and impacts on the private sector}

\begin{abstract}
The search for tax credit satisfaction is a great challenge for public administration. The analysis of the relevant aspects about the possibility of protest of the Certificate of Active Debt (CDA) of fiscal nature, from the correct interpretation of the constitutional text is necessary in a context of political and economic crisis. The confirmation of the constitutionality of the protest by the Federal Supreme Court reveals several aspects, such as the possible characterization of a political sanction that impacts business activity. This environment of discouragement of private economic activity, the CDA protest of fiscal nature shows itself as another ingredient.
\end{abstract}

Keywords: Protest; Certificate of Active Debt; Tributary; Business activity; Development.

\section{INTRODUÇÃO}

O mundo tem enfrentado alguns momentos de grave instabilidade econômica e o Brasil vem passando por tal situação de forma bem mais profunda nos últimos anos. Há, sem dúvida, a necessidade de superação de um momento político e econômico bastante crítico, momento esse onde a crise fiscal, aí incluída o déficit de arrecadação frente aos gastos públicos, é agente que aprofunda ainda mais os problemas e as consequências suportadas principalmente pelo cidadão.

\footnotetext{
${ }^{1}$ Bolsista PNPD na Universidade de Marília (UNIMAR). Doutor em Direitos Humanos e Desenvolvimento e Mestre em Direito Econômico, ambos pela Universidade Federal da Paraíba (UFPB). Especialista em Direito Tributário pela UNISUL. Advogado e Professor. E-mail: bbastos.adv@gmail.com

${ }^{2}$ Mestranda em Direito pela Universidade de Marília (UNIMAR). Pós-graduanda em Direito de Família e Sucessões pela Damásio Educacional. E-mail: mariamacenaadv@ gmail.com 
Nesse cenário, a intenção arrecadatória estatal ganha proporções muitas vezes absurdas. São nesses momentos de fragilidade institucional e política que se torna propícia a violação de direitos fundamentais, bem como a adoção de medidas arbitrárias e incompatíveis com a ordem constitucional posta. É nesse contexto que se aprofundou o debate sobre a possibilidade de protesto da Certidão de Dívida Ativa - CDA, debate esse que vem sendo esquecido, especialmente após o Supremo Tribunal Federal entender pela constitucionalidade de tal medida.

Primeiramente, necessário destacar que dívida ativa é o crédito fazendário não adimplido no prazo legal, podendo ser de natureza tributária ou não. Ou seja, é um débito que o particular possui com a administração pública (União, Estado, Distrito Federal ou Município), e que na ausência de pagamento é inscrito em dívida ativa. $\mathrm{O}$ documento que atesta a referida dívida é a "Certidão de Dívida Ativa" ou "CDA", que é título executivo extrajudicial, caracterizado pela liquidez (valor da dívida), certeza (existência e veracidade), e exigibilidade (cobrança).

Por tais razões, a CDA é documento indispensável para o ajuizamento da "Ação de Execução Fiscal”, conforme dispõe a Lei nº 6.830/1980. Com base nessas informações é indiscutível que a referida ação é meio adequado e satisfatório para a cobrança de crédito fazendário, não adimplido no prazo. Sendo assim, qual a razão de se admitir o protesto de dívida ativa, ou a quem interessa?

Protesto é ato solene, realizado em cartório pelo tabelião, cuja principal finalidade é comprovar a ausência de pagamento de um título de crédito, por exemplo, um cheque, ou de demais documentos sujeito ao protesto. Sendo assim o protesto afirma a existência da dívida e resguarda o crédito de quem protestou. No âmbito do Poder Judiciário, no que diz respeito às dívidas fazendárias, o protesto não tem o condão de alterar nada, haja vista que no caso em análise a própria CDA garante a execução, pois o executado (devedor) já é citado para efetuar pagamento sob pena de medidas mais drásticas. Fora do Poder Judiciário, e de modo geral, o protesto da ciência a terceiros (empresas, especialmente financeiras), através de órgãos de proteção ao crédito que após consultar a certidão de protestos, promovem a inscrição do devedor no cadastro de inadimplentes, que certamente dará o norte na realização ou não de novos negócios.

A polêmica acerca da possibilidade de protesto de CDA é antiga, mas se intensificou com edição da Lei ${ }^{\circ} 12.767 / 2012$, responsável por inserir na Lei ${ }^{\circ}$ 9.492/97, a possibilidade 
expressa do mencionado ato. Quem defende se baseia em economia, celeridade e eficácia na satisfação do credito fazendário, argumentando ainda que o protesto evitaria a propositura de novas ações executivas, dentre outras alegações. De modo contrário, o entendimento é de que o protesto caracterizaria "sanção política", ainda que indireta ao livre exercício de trabalho ou de qualquer atividade econômica, tendo em vista que o protesto dificulta ou inviabiliza a obtenção de crédito, gerando sério prejuízo para o fechamento de novos negócios e parcerias. Ora se já existe um meio legal e específico para a cobrança do crédito fazendário (Lei $\mathrm{n}^{\circ}$ 6.830/1980), não é razoável o protesto. Ademais admitir o protesto da CDA é ir de encontro ao chamado "Princípio da menor onerosidade", que ensina que o credor, e na inobservância deste o Juiz, deverá observar o modo menos gravoso de executar o credor.

O embate traçado em relação a matéria perante os juízes e tribunais de todo o País, chegou ao Supremo Tribunal Federal - STF, por meio da Ação Direta de Inconstitucionalidade (ADI) n 5135, proposta em junho de 2014, pela "Confederação Nacional da Indústria - CNI", que apesar de julgada improcedente, não pode por fim às discussões acerca do tema.

\section{A SATISFAÇÃO DO CRÉDITO TRIBUTÁRIO E OS MECANISMOS POSTOS A DISPOSIÇÃO DA FAZENDA PÚBLICA}

Inicialmente, faz-se necessário assentar como o crédito de natureza fiscal via de regra é cobrado pela Fazenda Pública, não havendo dúvidas no sentido de que a busca pela satisfação desse crédito é fundamental para que o Estado possa gerir o estoque de dívida ativa que possui, buscando assim receitas que possam colaborar para que os serviços essenciais sejam realizados.

\subsection{O PROCESSO DE EXECUÇÃO FISCAL E A CERTIDÃO DE DÍVIDA ATIVA}

O conceito de dívida ativa "abrange os créditos a favor da Fazenda Pública, cuja certeza e liquidez foram apuradas, por não terem sido efetivamente recebidos nas datas aprazadas" (BRASIL, MINISTÉRIO DA FAZENDA, 2004, p. 11). Em outros termos, dívida ativa é o crédito fazendário não adimplido no prazo legal, ou seja, é um débito que o particular possui com a administração pública (União, Estado, Distrito Federal ou Município). 
Mister se faz ressaltar que a expressão "dívida ativa" é utilizada para se referir às dívidas de natureza tributária, bem como aquelas cuja origem não advém de uma relação tributária, portanto, de natureza não tributária. A relação jurídica estabelecida entre o particular e a Fazenda Pública determina a natureza jurídica da dívida - tributária ou não tributária -, conforme preceitua a redação do artigo $2^{\circ}$ da Lei ${ }^{\circ} 6.830 / 1980^{3}$.

Por sua vez, o parágrafo $2^{\circ}$, do artigo 39 , da Lei $\mathrm{n}^{\circ} 4.320 / 1964^{4}$, diferencia o crédito tributário do não tributário.

Entretanto, necessário registrar que há entendimento doutrinário no sentido de que nem todo crédito fazendário é passivo de inscrição em dívida ativa. É o entendimento esposado por Leandro Paulsen, René Bergman Ávila e Ingrid Schroder Sliwka, segundo os quais:

(...) nem todo o crédito da Fazenda Pública pode ser inscrito em dívida ativa. Apenas aquele decorrente do poder de império ${ }^{5}$, exercido na modalidade de poder de polícia ou de outra atividade legalmente conferida à autoridade de direito público, enquanto atividade típica e própria da entidade de direito público, ainda que outros créditos possam ser considerados no conceito amplo de receita pública. Destarte a origem do crédito, se não decorrente do poder de império, deverá ser ato ou contrato administrativo típico, sendo que outros créditos regem-se pelas normas comuns de responsabilidade civil disciplinada pelo direito privado. Estão excluídos do conceito, por exemplo, os créditos decorrentes de dano ao patrimônio da pessoa jurídica de direito público ou os créditos cedidos por outros entes que hajam sido originários de atos ou contratos privados. (2010, p. 159).

Posta dessa maneira a questão, Flávia Coelho, em artigo que versa acerca do "conceito de dívida ativa não tributária e o entendimento da $\mathrm{PGFN}^{6}$ " orienta que o entendimento mais recente da PGFN, é no sentido de que os créditos de natureza não tributária, para serem objeto de inscrição em dívida ativa, não obstante o fundamento legal insculpido no $§ 2^{\circ}$, do art. 39, da Lei n ${ }^{\circ} 4.320 / 1964$, reclamam ainda "outra lei que preveja a cobrança administrativa do crédito" (2015).

\footnotetext{
${ }^{3}$ Lei no ${ }^{\circ}$ 6.830/1980. Art. $2^{\circ}$ - Constitui Dívida Ativa da Fazenda Pública aquela definida como tributária ou não tributária na Lei $\mathrm{n}^{\circ}$ 4.320, de 17 de março de 1964 , com as alterações posteriores, que estatui normas gerais de direito financeiro para elaboração e controle dos orçamentos e balanços da União, dos Estados, dos Municípios e do Distrito Federal.

$\S 1^{\circ}$ - Qualquer valor, cuja cobrança seja atribuída por lei às entidades de que trata o artigo $1^{\circ}$, será considerado Dívida Ativa da Fazenda Pública.

$\S 2^{\circ}$ - A Dívida Ativa da Fazenda Pública, compreendendo a tributária e a não tributária, abrange atualização monetária, juros e multa de mora e demais encargos previstos em lei ou contrato. (BRASIL, 1980).

${ }^{4}$ Estatui Normas Gerais de Direito Financeiro para elaboração e controle dos orçamentos e balanços da União, dos Estados, dos Municípios e do Distrito Federal.

${ }^{5}$ Atos de império são os que se caracterizam pelo poder de coerção decorrente do poder de império (ius imperii), não intervindo a vontade dos administrados para sua prática. Como exemplo, os atos de polícia (apreensão de bens, embargo de obra), os decretos de regulamentação etc. (CARVALHO, 2017, P. 114).

${ }^{6}$ Procuradoria Geral da Fazenda Nacional.
} 
Nessa perspectiva, observada a ressalva acima apontada, para que o crédito fazendário possa ser objeto de inscrição em dívida ativa, é necessário que o mesmo seja certo e líquido, é o que determinam os artigos. $2^{\circ}$ e $3^{\circ}$ da Lei $n^{\circ} 6.380 / 1980$ e o $39, \S 2^{\circ}$, da Lei $n^{\circ} 4.320 / 1964$. Tais características são apuradas pelos órgãos competentes, instituído por cada ente fazendário, antes da inscrição do crédito em dívida ativa.

Sobre a inscrição do crédito em dívida ativa, é preciso ter-se em mente que se trata de ato administrativo vinculado, por meio do qual "a Fazenda Pública unilateralmente declara que alguém deve e elabora um documento que dá presunção de liquidez e certeza da existência de tal débito" (ALEXANDRE, 2017, p. 625). Tal ato resulta na emissão da Certidão de Dívida Ativa (CDA), que é título executivo extrajudicial ${ }^{7}$, dotado de certeza e liquidez, conforme dispõe o artigo $3^{\circ}$, da Lei no 6.830/1980, e o artigo 204 do Código Tributário Nacional.

A Certidão de Dívida Ativa (CDA) é documento indispensável para a propositura da execução fiscal, e deve conter os requisitos prescritos na Lei $n^{\circ} 6.830 / 1980$ (art. $2^{\circ}, \S 5^{\circ}$ ), reiterados por meio do art. 202 do CTN. A recuperação de crédito fiscal por meio da ação de execução encontra-se prescrita no artigo 38 da Lei $n^{\circ}$ 6.830/1980, transcreve-se:

\begin{abstract}
A discussão judicial da Dívida Ativa da Fazenda Pública só é admissível em execução, na forma desta Lei, salvo as hipóteses de mandado de segurança, ação de repetição do indébito ou ação anulatória do ato declarativo da dívida, esta precedida do depósito preparatório do valor do débito, monetariamente corrigido e acrescido dos juros e multa de mora e demais encargos. (BRASIL, 1980).
\end{abstract}

Cumpre esclarecer que em termos processuais, conforme alerta Ricardo Alexandre (2017, p. 624) a Lei das Execuções Fiscais (LEF) trata da mesma forma a execução de crédito tributário e não tributário. A discussão proposta neste estudo reside justamente no fato de se utilizar do protesto da CDA como forma de coagir o contribuinte a efetivar o pagamento do débito fiscal.

\title{
2.2. ASPECTOS CONTROVERTIDOS DO PROTESTO CAMBIÁRIO COMO MODALIDADE DE COBRANÇA DE DÍVIDA ATIVA
}

\footnotetext{
${ }^{7}$ Art. 784 do Código de Processo Civil - “a certidão de dívida ativa das Fazendas Públicas, correspondentes aos créditos inscritos na forma da lei, é título executivo extrajudicial”. (BRASIL, 2015).
} 
Historicamente o protesto notarial sempre foi tratado no âmbito do direito comercial (SANTOS, 2012, p. 1).

Frise-se que o Direito Comercial foi definido por Georges Ripert como "a parte do Direito Privado que regula as operações jurídicas feitas pelos comerciantes, seja entre si, seja entre os seus clientes". (ABRÃO apud RIPERT, 2017).

Com base no exposto, percebe-se que o protesto é mecanismo de cobrança próprio das relações privadas. De outra banda, a inscrição de crédito fazendário em dívida ativa e, por conseguinte a ação de execução fiscal, são instrumentos de recuperação de crédito privativo da Fazenda Pública.

Superada a questão quanto a natureza jurídica do protesto, é preciso conceitua-lo. A definição legal de protesto se encontra prescrita no artigo $1^{\circ}$ da Lei $n^{\circ} 9.492 / 1997$, como sendo "ato formal e solene pelo qual se prova a inadimplência e o descumprimento de obrigação originada em títulos e outros documentos de dívida" (BRASIL, 1997).

Reforçando a ideia de que o protesto sempre foi praticado nas relações privadas, Fábio Ulhoa Coelho (2009, p. 415) registra que "o protesto deve-se definir como ato praticado pelo credor, perante o competente cartório, para fins de incorporar ao título de crédito a prova de fato relevante para as relações cambiais".

Não obstante o protesto ser inquestionavelmente mecanismo de cobrança típico das relações privadas, em 1997, com a edição da Lei $n^{\circ}$ 9.492, cuja finalidade é regulamentar os serviços concernentes ao protesto de títulos e "outros documentos de dívida", o fisco começou a advogar pela possibilidade de protestar créditos fazendários, argumentando que a expressão “outros títulos de dívida" autorizava o protesto de CDA.

Contudo, parte considerável da doutrina, mesmo após a edição da Lei no 12.767/2012 que inseriu expressamente a possibilidade de protesto das certidões de dívida ativa, por meio do parágrafo único na Lei $\mathrm{n}^{\circ} 9.492 / 1997$, tece veementes críticas ao protesto de CDA, a exemplo de Hugo de Brito Machado, in verbis:

O protesto de Certidão de Dívida Ativa consubstancia um evidente abuso porque absolutamente desnecessário para a propositura da execução fiscal. Nada acrescenta ao crédito tributário (...). Não há dúvida de que nenhum dos efeitos legais do protesto se faz necessário, ou pertinente, ao crédito tributário. O protesto de CDA, portanto, constitui apenas uma forma arbitrária de causar constrangimento indevido ao contribuinte, na esperança de que este, para evita-lo, faça o pagamento sem nada questionar, sem exercitar o seu direito de defesa contra cobranças indevidas. (2017). 
De fato, o protesto de CDA não aproveita a Fazenda Pública, portanto, é desnecessário, senão vejamos:

O art. 202, incs. II e III do CC prevê que a interrupção da prescrição ocorre pelo protesto judicial ou por protesto cambial. No entanto, o CTN, art. 174, regula a matéria da prescrição do crédito tributário, não sendo cabível a aplicação do CC quanto ao tema, até por este ser uma Lei Ordinária (Lei n. ${ }^{\circ}$ 10.406/2002), o que, se fosse o contrário, violaria o art. 146, inc. III, b, CF/88, e a exigência de Lei Complementar.

Vale dizer também que o protesto judicial a que os arts. 202, II, CC, e 174, II, CTN, se referem é o previsto nos arts. 867 a 873 do Código de Processo Civil, com a finalidade de "prevenir responsabilidade, prover a conservação e ressalva de seus direitos ou manifestar qualquer intenção de modo formal", sendo um instrumental processual totalmente diverso do protesto cambial. (...).

$\mathrm{O}$ art. 94 , caput, inc. I, e $\S \S 2^{\circ}$ e $3^{\circ}$ da Lei n. ${ }^{\circ} 11.101$ de 2005 , que regula os processos de recuperação judicial e falência, estabelecem o limite mínimo do valor líquido e certo de quarenta salários mínimos de obrigações materializadas em títulos executivos protestados para a requisição da falência do devedor, para o qual, por óbvio, se exige o protesto como instrumento que permita tal requerimento. Inicialmente, vale destacar que "não interessa para o Estado, para os credores ou para a própria sociedade a falência da sociedade - de acordo com sua viabilidade e o seu valor ao meio social" (LOVATO et all, 2013, p. 487), não sendo em nenhuma instância condizente acreditar que o protesto de CDAs vise o requerimento da falência do devedor, o que viola o princípio do interesse público e da adequação para ver sanados as dívidas fiscais. (LOVATO, NETO, p. 13).

Os apontamentos acima transcritos revelam que a Fazenda Pública não se aproveita dos efeitos decorrentes do protesto cambiário. A ausência de necessidade é um argumento importante, contudo, é necessário impor ao debate discussões acerca da constitucionalidade do protesto de CDA, matéria analisada a frente.

\section{PROTESTO DA CDA FISCAL E A IMPLEMENTAÇÃO DE UMA VIA POLÍTICA PARA ARRECADAÇÃO TRIBUTÁRIA: AS INCONSTITUCIONALIDADES OBSERVADAS}

Primeiramente, há que se destacar a patente inconstitucionalidade formal do parágrafo único do art. $1^{\circ}$ da Lei ${ }^{\circ}$ 9.492/1997.

A Medida Provisória $n^{\circ} 577 / 2012$, posteriormente convertida na Lei Ordinária de $n^{\circ}$ 12.767/2012, dispunha inicialmente acerca da “extinção das concessões de serviço público de energia elétrica e a prestação temporária do serviço e sobre a intervenção para adequação do serviço público de energia elétrica", contundo, em completo desrespeito às regras 
constitucionais do processo legislativo, foram inseridas matérias estranhas ao texto original, é o que a doutrina convencionou chamar de "contrabando legislativo".

Como é cediço, a conversão das medidas provisórias em lei ordinária segue um ritmo especial, trata-se na verdade de um processo legislativo célere, até mesmo em razão da presença obrigatória dos pressupostos de urgência e relevância para sua edição, conforme determina o artigo 62 da CRFB/1988. Frise-se que o processo legislativo de modo geral se submete aos ditames estabelecidos pela Constituição Federal, Lei Complementar $n^{\circ} 95 / 98^{8}$, e por fim na Resolução do Congresso Nacional $n^{\circ} 1$ de $2002^{9}$.

As normas apontadas proíbem expressamente a inserção de matéria estranha ao objeto da lei, transcreve-se:

LC $n^{\circ} 95 / 98$. Art. $7^{\circ} \mathrm{O}$ primeiro artigo do texto indicará o objeto da lei e o respectivo âmbito de aplicação, observados os seguintes princípios:

(...)

II - a lei não conterá matéria estranha a seu objeto ou a este não vinculada por afinidade, pertinência ou conexão;

III - o âmbito de aplicação da lei será estabelecido de forma tão específica quanto o possibilite o conhecimento técnico ou científico da área respectiva;

Especialmente em relação as emedas oferecidas em sede de medida provisória:

Resolução do Congresso Nacional $n^{\circ} 1$ de 2002. Art. $4^{\circ}$ Nos 6 (seis) primeiros dias que se seguirem à publicação da Medida Provisória no Diário Oficial da União, poderão a ela ser oferecidas emendas, que deverão ser protocolizadas na SecretariaGeral da Mesa do Senado Federal.

(...)

$\S 4^{\circ}$ É vedada a apresentação de emendas que versem sobre matéria estranha àquela tratada na Medida Provisória, cabendo ao Presidente da Comissão o seu indeferimento liminar.

Examinado o texto supratranscrito percebe-se que não se tratam de normas constitucionais, razão pela qual não serve de parâmetro de constitucionalidade. Contundo, o Supremo Tribunal Federal, no julgamento da Ação Direta de Inconstitucionalidade $\mathrm{n}^{\mathrm{o}} 5$. 127/DF, manifestou entendimento de que a prática do contrabando legislativo viola o direito fundamental ao processo legislativo.

\footnotetext{
${ }^{8}$ Dispõe sobre a elaboração, a redação, a alteração e a consolidação das leis, conforme determina o parágrafo único do art. 59 da Constituição Federal, e estabelece normas para a consolidação dos atos normativos que menciona.

${ }^{9}$ Dispõe sobre a apreciação, pelo Congresso Nacional, das Medidas Provisórias a que se refere o art. 62 da Constituição Federal, e dá outras providências.
} 
Diante de tais apontamentos questiona-se: "o que explicaria, então, a prática recorrente do "contrabando" legislativo, que desafia o devido processo legislativo democrático e constitucional e compromete a higidez da produção normativa?" (TRINDADE, 2015, p. 37). A pergunta é pertinente, e encontra resposta justamente na vontade política (tanto do Executivo, como do Legislativo) de aprovar matéria de interesse próprio ou de determinadas classes, sem o devido debate, em razão da celeridade da tramitação das medidas provisória. (SANTOS, 2015).

Superado o debate acerca da inconstitucionalidade formal pela prática do contrabando legislativo, mister se faz ressaltar que o STF, sob o argumento de preservação da segurança jurídica (artigo $1^{\circ}$ e $5^{\circ}, \mathrm{XXXVI,} \mathrm{CRFB),} \mathrm{determinou} \mathrm{a} \mathrm{manutenção} \mathrm{de} \mathrm{todas} \mathrm{as} \mathrm{leis} \mathrm{de} \mathrm{conversão}$ fruto dessa prática promulgadas até a data do presente julgamento (15/10/2015), bem como aquelas que ainda estavam em tramitação, conferindo assim, eficácia prospectiva.

Em resumo, eis a razão pela qual o STF, não obstante manifestar entendimento pela inconstitucionalidade do contrabando legislativo, afastar a inconstitucionalidade do parágrafo único do art. $1^{\circ}$ da Lei $n^{\circ} 9.492 / 1997$, resultante da referida prática. Diante do exposto, é inevitável questionar, especialmente no caso de protesto de CDA, que permanece cercado de controvérsias, se a improcedência da Ação Direta de Inconstitucionalidade (ADI) no 5135, sob a análise formal, produz menos efeitos adversos do que a decisão em sentido contrário. Acredita-se que a resposta para tal indagação exige uma avaliação acerca da inconstitucionalidade material.

Fato é que a inconstitucionalidade material a ser sustentada na sequencia se liga diretamente à nítida limitação da atividade empresarial, afrontando assim preceitos constitucionais, tal como o princípio da preservação da empresa.

A Ação Direita de Inconstitucionalidade n ${ }^{\circ} 5135$, proposta pela Confederação Nacional das Indústrias - CNI, fundamenta a inconstitucionalidade material do protesto de CDA, principalmente nos seguintes termos:

(...) considerando a restrição às atividades do devedor que o protesto é capaz de provocar, em razão da publicidade de uma suposta impontualidade no cumprimento da obrigação, geradora, como notório, de uma restrição do crédito comercial, o protesto da CDA estaria a afrontar os postulados constitucionais que visam a assegurar a livre prática de atividade econômica lícita (parágrafo único do art. 170 da CRFB) e a liberdade do exercício profissional (artigo $5^{\circ}$, XIII, da CRFB) (PETIÇAÕ INICIAL, ADI No 5135, 2014, p. 14). [Negritamos]. 
A livre iniciativa é um dos fundamentos da República Federativa do Brasil, conforme disposição do artigo. $1^{\circ}$, inciso IV, CRFB/1988. Especialmente no Título VII, logo no capítulo I, que trata "dos princípios gerais da atividade econômica", o constituinte reitera sua preocupação com a livre iniciativa ao dispor no art. 170 que “ a ordem econômica, fundada na valorização do trabalho humano e na livre iniciativa, tem por fim assegurar a todos existência digna, conforme os ditames da justiça social, observados os seguintes princípios”. Por sua vez acerca da liberdade do exercício profissional, o artigo $5^{\circ}$, inciso XIII, CRFB/1988, prescreve que "é livre o exercício de qualquer trabalho, ofício ou profissão, atendidas as qualificações profissionais que a lei estabelecer".

Celso Ribeiro Bastos pontua que a livre iniciativa é "uma manifestação dos direitos fundamentais" (1990, p. 16). Sendo assim, é preciso alertar que a livre iniciativa, assim como os demais direitos fundamentais, não é absoluta, podendo o Estado intervir para regular determinadas situações, como por exemplo, intervir no preço de determinados produtos, todavia, tal intervenção não pode impossibilitar a atividade humana. Entende-se, portanto, que a limitação ou exigência imposta pelo Estado somente se justifica quando tem o condão de gerar efeitos positivos para a coletividade ou impedir consequências negativas, se não é possível observar tal (is) feito (s) pode-se afirmar que a limitação é inconstitucional, por violar direito fundamental.

Posta dessa maneira a questão, tem-se que qualquer ato administrativo ou normativo que dificulte ou proíba o exercício despropositado da livre iniciativa, padece de inconstitucionalidade material. De mais a mais, especificamente quando se trata de crédito de natureza tributária, obstar a livre iniciativa, por meio de práticas abusivas (desnecessárias e desproporcionais), impede, não só o pagamento do tributo objeto da cobrança, na realidade a prática afeta o adimplemento de outros créditos fazendários, comprometendo a receita de outros Entes.

Não é forçoso rememorar que no Estado Social pagar tributos é considerado direito fundamental, uma vez que é justamente com essa receita - principal fonte de arrecadação do Estado - que se custeia diversos direitos fundamentais, como saúde, educação, segurança pública, dentre outros. Nesse sentido, transcreve-se a lição de Marcelo Martins Altoé:

Os deveres fundamentais justificam, portanto, os custos que suportam os integrantes da comunidade, para que a mesma exista, funcione e, ainda, realize os direitos fundamentais previstos na Carta Fundamental à qual se sujeita esta comunidade. Entre 
os custos suportados pelos indivíduos que compõem esta sociedade destaca-se o custo financeiro, consubstanciado no dever de pagar tributos. (2009, p. 81).

Não obstante o texto se referir apenas ao crédito de natureza tributária, não se pode desprezar que a cobrança por meio inadequado - protesto de CDA - de crédito não tributário, produz o mesmo resultado na atividade empresarial ou no exercício profissional de uma atividade, considerando que o protesto gera efeito cascata, dificultando, por exemplo, o acesso a créditos financeiros já que a pessoa (física ou jurídica) tem seu nome incluído nos cadastros de maus pagadores.

Além da consequência supracitada, existem outras como a impossibilidade de emissão de certidões negativas, contudo, a restrição do crédito pode ser considerada o efeito mais nefasto do protesto de CDA, uma vez que

\begin{abstract}
O capital é a mola propulsora a alavancar qualquer atividade econômica, portanto, a restrição ao crédito para uma empresa é o mesmo que a decretação de sua morte, pois, sem acesso ao recurso financeiro, resta ao empresário cerrar portas e interromper sua atividade produtiva, deixando de gerar empregos, renda e tributos.

A Fazenda Pública ao se valer do protesto para compelir o contribuinte a pagar tributo vai de encontro com o interesse público, pois deixa de se utilizar da via adequada de cobrança posta a sua disposição através da execução fiscal, impõem ao sujeito passivo pesadas restrições no campo do crédito, atentando ainda contra a livre iniciativa consagrada na Carta Magna, visto que obstaculiza a continuidade da empresa, o que configura a aplicação de sanção política. (BASTOS, 2016 p. 12).
\end{abstract}

É preciso ter-se em mente que o exercício da livre iniciativa e, por conseguinte da atividade empresarial é direito assegurado na Magna Carta de 1988. Não se pode deixar de elogiar a inteligência do constituinte, uma vez que a preservação de tais direitos tem repercussão social, ou seja, limitar ou inviabilizar a atividade empresarial é prejudicial a coletividade.

Partindo dessa acepção, convém ressaltar que o princípio da preservação da empresa, não obstante não se encontrar expresso na Constituição Federal, dada a sua importância para o exercício de direitos como a dignidade da pessoa humana e o pleno emprego, por exemplo, é considerado pela doutrina e jurisprudência como princípio constitucional. Acerca da importância da preservação da empresa, transcreve-se os ensinamentos de Carlos Alberto Farracha de Castro:

não se pode falar em busca do pleno emprego, sem propiciar a preservação da empresa (...). Afinal, o exercício da atividade empresarial é a fonte de tributos e empregos. Ou seja, sem a preservação da atividade empresarial inexiste emprego, razão pela qual 
não há como valorizar o trabalho, motivo por que a pretensão do legislador constituinte ficaria reservada ao seu emprego (2007, p. 43).

Isto posto, não se pode olvidar que o protesto de CDA é contrário ao texto constitucional, uma vez que afronta a livre iniciativa e constitui obstáculo a preservação da empresa, prejudicando o empresário que investe suas economias e a força de seu trabalho no desempenho de inúmeras atividades e, por conseguinte, afeta de forma negativa a coletividade que sofre continuamente com a falta de emprego, saúde, educação e segurança.

Assim, quanto ao protesto de CDA, a despeito do Supremo Tribunal Federal se manifestar pela constitucionalidade, com todas as vênias, entende-se de forma contrária para afirmar que tal medida é inconstitucional, posto que impõe empecilho flagrante à livre iniciativa, bem como a preservação da empresa.

Por fim, é possível ainda entender o protesto de CDA como sendo instrumento de clara sanção política, reprovável, portanto, conforme se observa no próximo tópico do presente estudo.

\section{A CARACTERIZAÇÃO DE EVIDENTE SANÇÃO POLÍTICA NO PROTESTO DE CDA}

Por óbvio, a obrigação de quem deve é pagar enquanto é direito do credor consiste justamente na prerrogativa de poder cobrar o débito. No caso de a Fazenda Pública ser credora, via de regra ${ }^{10}$, inexiste discricionariedade para que se efetue a cobrança, ou seja, o ente público é obrigado a cobrar seus créditos, em razão do interesse público. Todavia, a busca pela satisfação do crédito fazendário não autoriza o fisco a agir de qualquer modo e a qualquer custo, sob pena da prática ser considerada sanção política.

É de Hugo de Brito Machado o conceito clássico de sanção política, para o autor a prática pode ser definida como "restrições ou proibições impostas ao contribuinte, como forma indireta de obrigá-lo ao pagamento de tributo". (1998, p. 46). O mencionado autor, clarifica ainda mais a ideia de sanção política ao apontar alguns exemplos, in verbis:

\footnotetext{
${ }^{10}$ Existem leis que permitem o não ajuizamento das ações de execução fiscal ou mesmo a desistência de demandas já ajuizadas, considerando, sobretudo um valor mínimo da execução. Cada Ente da Federação possui competência para dispor de leis nesse sentido,
} 
Em Direito Tributário a expressão sanções políticas corresponde a restrições ou proibições impostas ao contribuinte, como forma indireta de obrigá-lo ao pagamento do tributo, tais como a interdição do estabelecimento, a apreensão de mercadorias, o regime especial de fiscalização, entre outras. Qualquer que seja a restrição que implique cerceamento da liberdade de exercer atividade lícita é inconstitucional, porque contraria o disposto nos artigos $5^{\circ}$, inciso XIII, e 170, parágrafo único, do Estatuto Maior do País. (...) São exemplos mais comuns de sanções políticas a apreensão de mercadorias sem que a presença física destas seja necessária para a comprovação do que o físco aponta como ilícito; o denominado regime especial de fiscalização; a recusa de autorização para imprimir notas fiscais; a inscrição em cadastro de inadimplentes com as restrições daí decorrentes; a recusa de certidão negativa de débito quando não existe lançamento consumado contra o contribuinte; a suspensão e até o cancelamento da inscrição do contribuinte no respectivo cadastro, entre muitos outros. Todas essas práticas são flagrantemente inconstitucionais, entre outras razões, porque: a) implicam indevida restrição ao direito de exercer atividade econômica, independentemente de autorização de órgãos públicos, assegurado pelo art. 170, parágrafo único, da vigente Constituição Federal; e b) configuram cobrança sem o devido processo legal, com grave violação do direito de defesa do contribuinte, porque a autoridade que a este impõe a restrição não é a autoridade competente para apreciar se a exigência é ou não legal. (MACHADO, 1998, P. 46). [Negritamos].

Pois bem, como se pode observar a sanção política, dentre outras violações constitucionais, afronta diretamente a livre iniciativa, uma vez que impõe ao devedor restrições que sobre a justificativa de compelir o devedor a efetuar o pagamento do débito, acabam por inviabilizar a atividade empresarial do devedor.

A prática de sanção política, além de inconstitucional é extremamente maléfica para todas as partes envolvidas, explica-se: (i) o credor sofre já que não consegue manter a empresa, haja vista o abalo que sofre com a restrição de créditos; (ii) por mais absurdo que possa aparentar, a fazenda pública acaba dificultando ainda mais a satisfação do crédito. Ora, quando maior for a dificuldade do credor em estabilizar sua situação financeira, em razão das limitações impostas pela própria fazenda pública, menores serão as chances de quitação do débito fiscal; (iii) por fim, o ato inconstitucional, desproporcional e desarrazoado prejudica toda sociedade, sobretudo a parcela menos abastada, que depende quase que exclusivamente das ações sociais do Estado para sobreviver, ainda que sem o mínimo de dignidade.

Especialmente em relação ao protesto de CDA, durante bastante tempo, mais precisamente até o fim de 2013, perdurou o entendimento jurisprudencial de que se tratava de sanção política, uma vez que os feitos do protesto não aproveitavam a fazenda pública. O tema era matéria pacífica no Superior Tribunal de Justiça, conforme se depreende do julgado abaixo: 
(...) 2. A Certidão de Dívida Ativa além da presunção de certeza e liquidez é também ato que torna público o conteúdo do título, não havendo interesse de ser protestado, medida cujo efeito é a só publicidade. 3. É desnecessário e inócuo o protesto prévio da Certidão de Dívida Ativa. Eventual protesto não gera dano moral in re ipsa. (...) (REsp 1093601/RJ, Rel. Ministra ELIANA CALMON, SEGUNDA TURMA, julgado em 18/11/2008, DJe 15/12/2008. RDDT vol. 162, p. 109).

Contudo, a partir do julgamento do Recurso Especial n $\mathrm{n}^{\mathrm{o}} 1.126 .515 / \mathrm{PR}$, da relatoria do Ministro Herman Benjamin, o STJ passou a admitir o protesto de CDA. O referido julgamento representa um divisor de águas no tratamento dispensado ao tema, razão pela qual transcrevese parte do julgado.

(...) 13. A possibilidade do protesto da CDA não implica ofensa aos princípios do contraditório e do devido processo legal (...) A Lei 9.492/1997 deve ser interpretada em conjunto com o contexto histórico e social. De acordo com o "II Pacto Republicano de Estado por um sistema de Justiça mais acessível, ágil e efetivo", definiu-se como meta específica para dar agilidade e efetividade à prestação jurisdicional a "revisão da legislação referente à cobrança da dívida ativa da Fazenda Pública, com vistas à racionalização dos procedimentos em âmbito judicial e administrativo". (...) Nesse sentido, o CNJ considerou que estão conformes com o princípio da legalidade normas expedidas pelas Corregedorias de Justiça dos Estados do Rio de Janeiro e de Goiás que, respectivamente, orientam seus órgãos a providenciar e admitir o protesto de CDA e de sentenças condenatórias transitadas em julgado, relacionadas às obrigações alimentares. (...) A interpretação contextualizada da Lei 9.492/1997 representa medida que corrobora a tendência moderna de intersecção dos regimes jurídicos próprios do Direito Público e Privado. A todo instante vem crescendo a publicização do Direito Privado (...) e, por outro lado, a privatização do Direito Público.(...) Recurso Especial provido, com superação da jurisprudência do STJ.(REsp 1126515/PR, Rel. Ministro HERMAN BENJAMIN, SEGUNDA TURMA, julgado em 03/12/2013, DJe 16/12/2013)

A matéria chegou ao Supremo Tribunal Federal - STF, por meio da Ação Direta de Inconstitucionalidade (ADI) $n^{\circ}$ 5135, proposta em junho de 2014, pela "Confederação Nacional da Indústria - CNI", que pleiteava a declaração de inconstitucionalidade do artigo $1^{\circ}$, da Lei ${ }^{\circ}$ 9.492/1997, introduzido por meio da Lei $\mathrm{n}^{\circ}$ 12.767/2012, que prevê expressamente a possibilidade de protesto de CDA. A ação foi julgada pelo Pleno do STF no dia 09 de novembro de 2016, e a maioria dos Ministros entendeu pela constitucionalidade do protesto de CDA, os votos divergentes foram dos Ministros Edson Fachin, Marco Aurélio e Ricardo Lewandowski, in verbis:

Decisão: O Tribunal, por maioria e nos termos do voto do Relator, julgou improcedente o pedido formulado, vencidos os Ministros Edson Fachin, Marco Aurélio e Ricardo Lewandowski. Fixada tese nos seguintes termos: "O protesto das Certidões de Dívida Ativa constitui mecanismo constitucional e legítimo, por não 
restringir de forma desproporcional quaisquer direitos fundamentais garantidos aos contribuintes e, assim, não constituir sanção política". O Ministro Marco Aurélio, vencido no mérito, não participou da fixação da tese. Ausentes, justificadamente, os Ministros Gilmar Mendes e Teori Zavascki, participando em missão oficial do Programa de Eleições dos Estados Unidos (USEP) e da $7^{\mathrm{a}}$ Conferência da Organização Global de Eleições (GEO-7), em Washington, Estados Unidos, e o Ministro Dias Toffoli, acompanhando as eleições norte-americanas a convite da International Foundation for Electoral Systems (IFES). Presidiu o julgamento a Ministra Cármen Lúcia. Plenário, 09.11.2016.

Interessante salientar que a declaração de constitucionalidade de protesto de CDA, assim como ocorreu no STJ, é resultando de mudança do entendimento anteriormente defendido por aquela Corte. Apenas para registro, transcreve-se o voto no qual o Ministro Edson Fachin, no julgamento do ARE 914045 RG/MG, posicionou-se do seguinte modo: "O Supremo Tribunal Federal tem reiteradamente entendido que é inconstitucional restrição imposta pelo Estado ao livre exercício de atividade econômica ou profissional, quanto aquelas forem utilizadas como meio de cobrança indireta de tributos". (STF, 2015).

Ao cabo dos argumentos anteriormente apresentados, apesar da declaração de constitucionalidade do protesto de CDA, mantém-se o entendimento de que tal prática é abusiva e desnecessária, além de extremamente prejudicial a livre iniciativa, portanto, restringe direito fundamental. Desse modo, tem-se a pior face da injustiça e da inconstitucionalidade, que é justamente aquela manifesta, legalizada e considerada “devida" pelo Poder Judiciário.

\subsection{INEFICIÊNCIA DA ADMINISTRAÇÃO PÚBLICA E O AUMENTO DO ESTOQUE FISCAL}

Um dos principais argumentos utilizados para justificar o protesto de CDA é justamente a ideia de que a execução fiscal é ineficiente. Pois bem, conforme demostrado anteriormente o protesto de CDA é meio coercitivo de cobrança fiscal, portanto, entende-se que tal prática configura sanção política, sendo assim, ainda que se entenda por verdade que a execução fiscal é ineficiente, o argumento não torna válido a prática do protesto.

Ora, sabe-se que a eficiência é um dos princípios constitucionais que devem orientar a Administração Pública, conforme preconiza o artigo 37 da CRFB/1988, todavia, assim como os demais direitos e princípios não se revestem de caráter absoluto, a eficiência deve ser 
observada conjuntamente com outros princípios, do contrário seria justificável qualquer prática, ainda que violadora de direitos, para garantir a eficiência.

Acontece que ao contrário do que se argumenta, a execução fiscal, quando utilizada para recuperar crédito fiscal, sobretudo aqueles de natureza tributária é mecanismo de cobrança eficiente. Outro ponto que merece destaque é, que as execuções fiscais propostas perante a Justiça Federal, não buscam em sua maioria satisfazer crédito fazendário. Explica-se.

A eficiência no processo de execução fiscal é medida por meio do comparativo entre o valor gasto com o processo e o crédito recuperado. Pois bem, em pesquisa realizada em varas da Justiça Federal no ano de 2011, pelo Instituto de Pesquisa Econômica Avançada - Ipea, verificou-se que

(...) o grau de sucesso das ações de execução fiscal é relativamente alto, uma vez que em $33,9 \%$ dos casos a baixa ocorre em virtude do pagamento integral da dívida ${ }^{11}$, índice que sobe para $45 \%$ nos casos em que houve citação pessoal. Vale destacar, entretanto, que a extinção por prescrição ou decadência é o segundo principal motivo de baixa, respondendo por $27,7 \%$ dos casos. Em seguida, vem o cancelamento da inscrição do débito (17\%) e a extinção sem julgamento do mérito $(11,5 \%)$. Causas menores de baixa incluem a remissão (8\%), o julgamento de embargos favoravelmente ao devedor $(1,3 \%)$, o julgamento de objeção de pre-executividade favoravelmente ao devedor $(0,3 \%)$ e o declínio de competência $(0,2 \%)$. Ao final, $12,3 \%$ das sentenças de execução fiscal são recorridas, em regra pelo exequente. (IPEA, 2011, p. 19/20).

O estudo revela que os índices de extinção da execução por pagamento do débito e em razão da prescrição ou decadência é praticamente idêntico, o que pressupõe que o sucesso ou insucesso na recuperação do crédito fiscal, na maioria dos casos, depende do próprio exequente. A morosidade em constituir a certidão de dívida ativa resulta justamente na impossibilidade futura de cobrar o débito, o que permite questionar se a ineficiência é do processo de cobrança ou do responsável por ela.

Outro fato revelado pela pesquisa aponta que a execução de crédito fiscal fazendário, não é sozinho a causa do congestionamento das varas fiscais, é que "os conselhos de fiscalização das profissões liberais aparecem como os grandes usuários dos procedimentos de execução fiscal na Justiça Federal” (IPEA, 2011, p. 17).

\footnotetext{
11 (...) a quitação do débito em parcela única, perante o exequente ou o juízo da execução, ocorre em $41,3 \%$ dos casos. A adesão e fiel cumprimento a programa de parcelamento da dívida representam $36,3 \%$ das ações extintas por pagamento. Contrariamente ao senso comum, o grau de respeito aos programas de parcelamento mostra-se extraordinariamente elevado: $64,4 \%$ dos executados que aderem a programas de parcelamento cumprem integralmente com as obrigações pactuadas em pelo menos um dos casos. (IPEA, 2011, p. 20).
} 
Diante do exposto, é possível concluir que a ineficiência da execução e a justificativa de que a execução de créditos fiscais fazendários são o grande entrave do Poder Judiciário, não revelam em sua totalidade a verdade dos fatos. Por outro ângulo, o protesto de CDA pode desencadear inúmeras demandas, cujo objetivo será justamente a sustação de protesto. Desse modo, o que se pretende equivocadamente com o protesto de CDA, muito provavelmente acarretará efeito adverso, tornado a recuperação do crédito fazendário cada vez mais difícil de acontecer e, por conseguinte abarrotando ainda mais o Poder Judiciário.

\section{CONSIDERAÇÕES FINAIS}

Após tudo que foi exposto, possível concluir que para implementar os objetivos fundamentais da República Federativa do Brasil é preciso que o país possa superar o estágio de estagnação econômica, social e política. Para tanto, o enfrentamento à crise fiscal se mostra fundamental, ou seja, o país necessita passar por uma necessária reforma tributária que possa reestruturar o Sistema Tributário Nacional, enfrentando de forma decisiva a questão do déficit de arrecadação existente, bem como o grande estoque fiscal que os entes da federação acumulam, visando sempre a efetivação do desenvolvimento econômico e não meramente um crescimento desenfreado, custe o que custar.

Nesse cenário, destaca-se a importância de refletir e enfrentar as opções da administração pública diante dessa verdadeira cruzada com o objetivo arrecadatório, sendo justamente aí que se situa a discussão sobre a constitucionalidade ou não do protesto de CDA.

Conforme discutido acima, o protesto de CDA assume caráter predominantemente político, numa tentativa da administração tributária forçar o contribuinte a efetivamente quitar um débito fiscal, débito esse que muitas vezes é constituído de maneira abusiva e indevida, podendo, inclusive, ser objeto de contestação administrativa ou judicial, a depender da situação concreta e da opção do contribuinte.

Importante ressaltar que, na maioria das vezes, o contribuinte não participa - ou participa de maneira muito tímida - da constituição do crédito tributário. Até mesmo nos lançamentos por homologação, onde o contribuinte efetivamente assume o papel de realização de verdadeiro auto-lançamento, a situação deste perante o Estado é de vulnerabilidade evidente. 
Soma-se a essa vulnerabilidade (desigualdade verificada na relação jurídica tributária) o fato de, em momento de crise, a pressão fiscal sobre o contribuinte aumentar significativamente.

Assim, nos parece evidente que a busca pela recuperação de crédito tributários não pode prevalecer sobre os preceitos jurídicos básicos que norteiam a ordem constitucional vigente. Nesse aspectos, o protesto da CDA vai de encontro a preceitos fundamentais, se caracterizando como verdadeira sanção política e inviabilizando ainda mais a exploração da atividade econômica pelo setor privado, já tão massacrado por um sistema de tributação injusto e voraz.

Ademais, cumpre ressaltar ainda que o protesto de CDA não pode se fundar em uma suposta alternativa ao congestionamento do Poder Judiciário, vez que a ineficácia do processo executivo fiscal se dá por vários motivos, muitos deles recaindo sob a responsabilidade da própria Fazenda Pública.

Em que pese todos os argumentos utilizados pelo Supremo Tribunal Federal para declarar a constitucionalidade do protesto de CDA, numa decisão evidentemente política, data máxima vênia, mantém-se o entendimento de que tal prática é abusiva e desnecessária, além de extremamente prejudicial a livre iniciativa, afrontando de morte preceitos constitucionais que deveriam estar preservados e garantidos.

Fato é que o custo da exploração de qualquer atividade econômica no Brasil, por parte da iniciativa privada, é extremamente alto, sendo que a validação constitucional do protesto da CDA somente contribui ainda mais para o aprofundamento desse quadro de desestímulo à atividade empresarial, impactando diretamente no dia a dia das empresas e colaborando para que haja crescente enfraquecimento do setor.

\section{REFERÊNCIAS}

ALEXANDRE, Ricardo. Direito Tributário. $11^{\mathrm{a}}$ edição, revisada, atualizada e ampliada. Salvador: JusPodivm, 2017.

ALTOÉ, Marcelo Martins. Direito versus dever tributário: colisão de direitos fundamentais. São Paulo: Revista dos Tribunais, 2009.

BASTOS, Celso Ribeiro; MARTINS, Ives Granda. Comentários à Constituição do Brasil. v.7, São Paulo: Saraiva, 1990. 
BASTOS, Jouber Rocha. Aspectos Controvertidos acerca do Protesto de Certidão de Dívida Ativa. Artigo apresentado apresentada à Faculdade de Internacional da Paraíba - FPB como requisito para a obtenção do título de Bacharel em Direito. João Pessoa: 2016. Disponível no acervo da biblioteca da faculdade. Acesso em 05 de novembro de 2018.

BRASIL. Ministério da Fazenda. Secretaria do Tesouro Nacional. Dívida Ativa: manual de procedimentos aplicado à União e aos Estados, Distrito Federal e Municípios. 1 ed.. Brasília. Disponível em: <http://www3.tesouro.gov.br/legislacao/download/contabilidade/Manual_Divida_Ativa.pdf_>. Acesso em 05 de novembro de 2018.

BRASIL. Lei no 4.320, de 17 de março de 1964. Estatui Normas Gerais de Direito Financeiro para elaboração e contrôle dos orçamentos e balanços da União, dos Estados, dos Municípios e do Distrito Federal. Disponível em: <http://www.planalto.gov.br/ccivil_03/leis/L4320.htm>. Acesso em 05 de novembro de 2018.

BRASIL. Lei $\mathrm{n}^{\mathbf{0}}$ 5.172, de 25 de outubro de 1966. Dispõe sobre o Sistema Tributário Nacional e institui normas gerais de direito tributário aplicáveis à União, Estados e Municípios. Disponível em: <http://www.planalto.gov.br/ccivil_03/leis/L5172Compilado.htm>. Acesso em 05 de novembro de 2018.

BRASIL. Lei $\mathbf{n}^{\circ}$ 6.830, de 22 de novembro de 1980. Dispõe sobre a cobrança judicial da Dívida Ativa da Fazenda Pública, e dá outras providências. Disponível em: <http://www.planalto.gov.br/ccivil_03/leis/L6830.htm>. Acesso em 05 de novembro de 2018.

BRASIL. Lei Complementar $n^{0}$ 95, de 26 de fevereiro de 1998. Dispõe sobre a elaboração, a redação, a alteração e a consolidação das leis, conforme determina o parágrafo único do art. 59 da Constituição Federal, e estabelece normas para a consolidação dos atos normativos que menciona. Disponível em: <http://www.planalto.gov.br/ccivil_03/leis/lcp/lcp95.htm>. Acesso em 05 de novembro de 2018.

BRASIL. Constituição da República Federativa do Brasil de 1988. Disponível em: <http://www.planalto.gov.br/ccivil_03/constituicao/constituicaocompilado.htm>.Acesso em 05 de novembro de 2018.

BRASIL. Lei $\mathbf{n}^{0}$ 9.492, de 10 de setembro de 1997. Define competência, regulamenta os serviços concernentes ao protesto de títulos e outros documentos de dívida e dá outras providências. Disponível em: <http://www.planalto.gov.br/ccivil_03/leis/L9492.htm>. Acesso em 05 de novembro de 2018.

BRASIL. Resolução no 1 , de 2002 do Congresso Nacional. Dispõe sobre a apreciação, pelo Congresso Nacional, das Medidas Provisórias a que se refere o art. 62 da Constituição Federal, e dá outras providências. Disponível em: <http://www2.camara.leg.br/legin/fed/rescon/2002/resolucao-1-8-maio-2002-497942normaatualizada-pl.html >. Acesso em 05 de dezembro de 2018. 
BRASIL. Lei n⿳ 12.767, de 27 de dezembro de 2012. Dispõe sobre a extinção das concessões de serviço público de energia elétrica e a prestação temporária do serviço e sobre a intervenção para adequação do serviço público de energia elétrica; altera as Leis nos 8.987, de 13 de fevereiro de 1995, 11.508, de 20 de julho de 2007, 11.484, de 31 de maio de 2007, 9.028, de 12 de abril de 1995, 9.492, de 10 de setembro de 1997, 10.931, de 2 de agosto de 2004, 12.024, de 27 de agosto de 2009, e 10.833, de 29 de dezembro de 2003; e dá outras providências. Disponível em: <http://www.planalto.gov.br/ccivil_03/_Ato20112014/2012/Lei/L12767.htm\#art25>. Acesso em 05 de janeiro de 2019.

BRASIL. Lei $\mathbf{n}^{\mathbf{0}}$ 13.105, de 16 de março de 2015. Código de Processo Civil. Disponível em: <http://www.planalto.gov.br/ccivil_03/_ato2015-2018/2015/lei/113105.htm>. Acesso em 05 de janeiro de 2019.

CARVAlHO FILHO, José dos Santos. Manual de Direito Administrativo. $31^{\mathrm{a}}$ edição, revisada, atualizada e ampliada. São Paulo: Atlas, 2017.

COELHO, Flávia. O conceito de Dívida Ativa não Tributária e o entendimento da PGFN. Disponível em: <https://blog.ebeji.com.br/o-conceito-de-divida-ativa-nao-tributario-e-oentendimento-da-pgfn/\#_ftnref2>. Acesso em 05 de janeiro de 2019.

COELHO, Fábio Ulhoa. Manual de Direito Comercial: direito de empresa $-21^{\text {a }}$ Ed., São Paulo: Saraiva, 2009.

CASTRO, Carlos Alberto Farracha de. Preservação da Empresa no Código Civil. Curitiba: Juruá, 2007.

IPEA, Instituto de Pesquisa Econômica Aplicada. Custo Unitário do Processo de Execução Fiscal na Justiça Federal: Relatório da Pesquisa Ipea. Conselho Nacional de Justiça. Brasília, 2011. Disponível em: <http://s.conjur.com.br/dl/pesquisa-ipea-cnj-custo-execucao-fiscal.pdf >. Acesso em 05 de janeiro de 2019.

LOVATO, Antonio Carlos; NETO, Renato Lovato. O Novo Parágrafo único do art. $\mathbf{1}^{\mathbf{0}}$ da Lei n. ${ }^{\circ}$ 9.492/1977 como Medida de Cobrança de Dívidas Fiscais: O Protesto de Certidão de Dívida Ativa. Disponível em: Disponível <http://www.publicadireito.com.br/artigos/?cod=4a9f57c5dadf5bc6>. Acesso em 05 de janeiro de 2019.

MARTINS, Fran. Curso de direito comercial. Atualizada por ABRÃO, Carlos Henrique. 40 edição, revisada, atualizada e ampliada. Rio de Janeiro: Forense, 2017.

MACHADO, Hugo de Brito. Protesto de Certidão de Dívida Ativa. Disponível em: < http://www.hugomachado.adv.br/>. Acesso em 08 de abril de 2017.

MACHADO, Hugo de Brito. Sanções Políticas no Direito Tributário. In: Revista Dialética de Direito Tributário, n. 30, p. 46, mar. 1998. 
PAULSEN, Leandro; ÁVILA, René Bergman; SLIWKA, Ingrid Schroder. Direito Processual Tributário - Processo Administrativo Fiscal e Execução Fiscal à luz da Doutrina e da Jurisprudência, $6^{\text {a }}$ ed. rev. atual. Porto Alegre: Livraria do Advogado, 2010.

SANTOS, Reinaldo Velloso dos Santos. Apontamentos sobre o protesto notarial. Dissertação de Mestrado - Faculdade de Direito da Universidade de São Paulo. São Paulo: 2012. Disponível em: < http://www.teses.usp.br/teses/disponiveis/2/2132/tde-20032013142914/pt-br.php>. Acesso em 05 de janeiro de 2019.

SANTOS, Luiz Alberto dos. MPs, jabutis e gambiarras: uma análise do processo legislativo e o papel das instituições. Brasília: Congresso em Foco, 2015.

STF, Supremo Tribunal Federal. ADI 5127 DF 2014. Relator Ministra Rosa Weber: Disponível em:

$<$ http://www.stf.jus.br/portal/peticaoInicial/verPeticaoInicial.asp?base=ADIN\&s1=5127\&pro cesso=5127>. Publicado em 11 de maio de 2016. Acessado em 05 de janeiro de 2019.

STF, Supremo Tribunal Federal. ADI 5135 DF 2014. Relator Ministro Roberto Barroso: Disponível

em

<http://www.stf.jus.br/portal/processo/verProcessoAndamento.asp?incidente=4588636>.

Publicado em 10 de fevereiro de 2017. Acessado em 05 de janeiro de 2019.

STF, Supremo Tribunal Federal. ADI 5135 DF 2014. Petição inicial da ADI. Disponível em $<$ http://redir.stf.jus.br/paginadorpub/paginador.jsp?docTP=TP\&docID=6110646\&ad=s\#2\%20 -\%20Peti\%E7\%E3o\%20inicial\%20-\%20Peticao\%20inicial\%201>. Acesso em 05 de janeiro de 2019.

STF, Supremo Tribunal Federal. ARE 914045 RG/MG. Relator: Ministro Edson Fachin. Disponível em <http://www.stf.jus.br/portal/jurisprudencia/listarJurisprudencia.asp?s1=\%28san\%E7\%E3o+p ol\%EDtica+\%29\&base=baseRepercussao\&url=http://tinyurl.com/prdw8mb $>$. Publicado em 19 de novembro de 2015. Acesso em 05 de janeiro de 2019.

STJ, Superior Tribunal de Justiça. REsp 1093601 RJ. Relator: Ministra Eliana Calmon. Disponível

em:

$<$ http://www.stj.jus.br/SCON/jurisprudencia/toc.jsp?data=\%40DTDE+\%3E\%3D+20081118+ $\mathrm{e}+\% 40 \mathrm{DTDE}+\% 3 \mathrm{C} \% 3 \mathrm{D}+20081118 \&$ livre $=\% 28 \% 22 \mathrm{ELIANA}+\mathrm{CALMON} \% 22 \% 29 . \mathrm{min} . \& \mathrm{pr}$ ocesso $=1093601 \& \& b=A C O R \&$ thesaurus $=$ JURIDICO $>$. Publicado em 15 de setembro de 2008. Acessado em 05 de janeiro de 2019.

STJ, Superior Tribunal de Justiça. REsp 1.126. 515 PR. Segunda Turma. Relator: Ministro Herman Benjamim. Disponível em: < https://ww2.stj.jus.br/processo/revista/inteiroteor/?num_registro=200900420648\&dt_publicac ao=16/12/2013 >. Publicado em 16 de dezembro de 2013. Acessado em 05 de janeiro de 2019.

TRINDADE, Alexandre de Sousa. Medidas Provisórias e Pertinência Temática: a importância do controle do "contrabando" legislativo como garantia da higidez da produção normativa infraconstitucional. Monografia apresentada à Faculdade de Direito da Universidade de Brasília como requisito para a obtenção do título de Bacharel em Direito. 
Brasília:

2015.

Disponível

em:

<http://bdm.unb.br/bitstream/10483/11949/1/2015_AlexandreTrindadedeSousa.pdf>. Acesso em 05 de janeiro de 2019.

VALADÃO, Marcos Aurélio Pereira; MENDONÇA, Maria Lírida Calou De Araújo e; FEITOSA, Raymundo Juliano (Orgs.). Direito tributário e financeiro I, Tema: Direito e Desigualdades. Brasília: CONPEDI, 2016, pág. 7/22. 